\title{
Original \\ Comparative Study of the Effect of Experimentally Induced Hyperthyroidism and Hypothyroidism on the Parotid Gland in Adult Male Albino Rats
} Article

\author{
Heba R. Hashem and Shereen Adel Saad
}

Anatomy and Embryology Department, Faculty of Medicine, Ain Shams University, Egypt

\begin{abstract}
Introduction: Thyroid dysfunctions are considered one of the most important endocrine disorders. Alterations in the level of thyroid hormones cause various subclinical or clinical manifestations. Salivary glands act as the biological media for food and the first line of defense for oral cavity and teeth. Any alterations in their integrity and activity can affect the patient's health. Aim: This study aimed to compare the possible histo-functional alterations that may occur in the parotid gland structure in an experimentally induced hyperthyroid and hypothyroid state.

Materials and Methods: Twenty four adult male rats were divided into three equal groups. Group I: served as euthyroid. Group II (hyperthyroid group): rats received Eltroxine in a dose $600 \mu \mathrm{g} / \mathrm{kg} /$ day via an oral gavage feeding needle for three successive weeks. Group III (hypothyroid group): rats received Neomercazole in a dose of $1.35 \mathrm{mg} / \mathrm{kg} / \mathrm{day}$ via an oral gavage feeding needle for three successive weeks. At the end of the experiment, all animals were weighed, blood samples were collected then all were sacrificed. The parotid glands were weighed and sampled for histopathological, Immunohistochemical and ultrastructural studies.

Results: Examination of parotid sections of treated groups showed histopathological changes in the form of swollen serous acini, vacuolation, dilated duct, changes in secretory granules density, congested blood vessels and cellular infiltration. That is accompanied by significant changes in parotid gland weight, rat's body weight, mast cell number, Bcl-2 positive cells and serum amylase.

Conclusion: It is recommended in cases of thyroid dysfunctions to monitor oral and dental health to follow salivary glands dysfunction.
\end{abstract}

Received: 29 September 2019, Accepted: 11 November 2019

Key Words: BCL-2, eltroxin, neomercazole, salivary glands, thyroid dysfunction.

Corresponding Author: Heba R. Hashem, PhD, Anatomy and Embryology Department, Faculty of Medicine, Ain Shams University, Cairo, Egypt, Tel.: +20 1006286556, E-mail: hebahramadan@gmail.com

ISSN: 1110-0559, Vol. 43, No.3

\section{INTRODUCTION}

Thyroid hormones (THs) are secreted by follicular cells in the thyroid gland in the form of thyroxine (T4) and triiodothyronine (T3) ${ }^{[1,2]}$. They are affecting most of the cells and tissues in the body. They are major regulators of basal metabolic rate and energy expenditure, being associated with different biological processes in all vertebrates ${ }^{[3,4]}$.

Thyroid hormones play an important role in cellular and neuronal development. They regulate reproductive functions, heart rate, body temperature, bone maturation, gastrointestinal motility and red blood cell production ${ }^{[2,5]}$. Also, they are involved in the regulation of oxidative metabolism and emotional stability. Besides, they control the metabolism of proteins, lipids, carbohydrate and have antioxidant enzyme activities ${ }^{[6,7]}$. Studies showed that thyroid hormones influence tissues because they facilitate DNA transcription, which results in the synthesis of new proteins ${ }^{[8]}$.

Hyperthyroidism is a hyper-metabolism resulting from increased freeT4 and/or free T3 serum levels ${ }^{[9]}$. This hypermetabolic state is accompanied by an increase in prooxidant to antioxidants ratio that leads to oxidative stress $^{[4,10]}$.

Particularly, hyperthyroidism, might ends up with common health problems such as cardiovascular diseases (heart failure and increased risk of heart attack), diabetes mellitus, oxidative damage of liver and osteoporosis ${ }^{[10]}$. Resemble the human hyperthyroidisms were easily achieved in rodents by treatment of 1-thyroxine (LT4), a synthetic form of thyroid hormone $e^{[10,11]}$.

On the other hand deficiency or absence of THs causes hypothyroidism. It is one of the most common thyroid disorders in humans that may be congenital or acquired ${ }^{[12]}$. It can result from impairment in mechanisms that control the formation of thyroid hormones or may arise as a result of complications during treatment of hyperthyroidism ${ }^{[4]}$.

The hypothyroid state is a complex hormonal dysfunction, manifested by a reversible slowing down of all body functions ${ }^{[13]}$. In hypothyroidism, the basal metabolic rate is decreased and production of reactive oxygen species (ROS) increased ${ }^{[1,14]}$. Metabolic depression occurred in hypothyroidism has been associated with a decrease in oxidant production ${ }^{[9,15]}$. 
Hypothyroidism was induced by anti-thyroid drug Carbimazole that is used in the treatment of human hyperthyroidism ${ }^{[4,16]}$.

Thyroid hormones are essential for epithelial differentiation and in modulating the sensitivity of the autonomic stimulation of salivary glands ${ }^{[8,17]}$.

Salivary glands; parotid, submandibular and sublingual secrete saliva, which acts not only as of the first biological media for food but also the first line of defense for oral cavity soft tissues and teeth ${ }^{[7]}$. Salivary secretions not only protect the oral mucosa and the teeth but also facilitating speech and solubilization of food substances ${ }^{[8,18]}$.

Salivary gland secretions are rich in fluids, ions, and proteins. It also produces antimicrobial substances which have an immediate effect on oral bacteria ${ }^{[12,19]}$. Also, saliva participates in immune defense mechanisms through antioxidative properties $^{[20,21]}$.

Any alterations in salivary glands integrity can change saliva flow and composition ${ }^{[12]}$. Several metabolic disorders can cause hyposalivation. Patients displaying hypo-salivary flow (xerostomia) suffer considerable morbidity. There are problems in eating, speaking, and swallowing and frequent disturbances in taste perception ${ }^{[8,19]}$.

5-HT-induced amylase secretion in rat's parotid gland was modulated by thyroid status ${ }^{[22]}$. Many studies have correlated between salivary gland dysfunction and autoimmune thyroiditis ${ }^{[7]}$. Hayat et al. $(2010)^{[13]}$ noticed that most of the hypothyroid patients were presented by salivary glands enlargement. It is noteworthy that thyroid function and oral health are closely associated.

Many studies correlated between hypothyroidism and parotid gland affection and few studies dealt with hyperthyroidism and parotid gland. So, this study aimed to compare the possible morpho-functional alterations that may occur in parotid gland structure in an experimentally induced hyperthyroid and hypothyroid state in adult male albino rats.

\section{MATERIALS AND METHODS}

\section{Experimental Animals}

Twenty four adult male albino rats of Wistar strain (six months age) weighing $250 \pm 15 \mathrm{~g}$ were used in the present study. Animals were obtained from the animal house of the Medical Research Center, Faculty of Medicine, Ain Shams University.

Rats were allowed free access to water and food and were housed in rooms with 12 hours day and night cycle, good hygienic conditions, good ventilation and of $21 \pm 3^{\circ} \mathrm{C}$. Animals were left one week for acclimatization before the start of the experiment. All animal procedures were approved by the animal care and use committee of the Faculty of Medicine Ain Shams University.

\section{Chemicals and Reagents}

- Thyroxine is the form of commercial tablets (Eltroxin) that was obtained from GlaxoSmithKline $\mathrm{GmbH}$, Germany.

- Carbimazole is the form of commercial tablets (NeoMercazol) that was obtained from Chemical Industries Development.

\section{Experimental Design}

At the onset of the study, blood samples were collected from the orbital vein of each rat for the measurement of thyroid hormones and amylase levels to exclude thyroid or parotid diseases.

The body weight of each animal was recorded at the start and on alternate days until the end of the experiments.

\section{Rats were randomly divided into three equal groups}

Group I (Euthyroid): Served as a control group and was subdivided into two equal subgroups:

Subgroup (i): kept without any treatment throughout the experiment.

Subgroup (ii): received $1 \mathrm{ml}$ of distilled water, the diluting vehicle for Eltroxine and Neomercazole via oral gavage feeding needle for three weeks.

Group II (hyperthyroid group): Rats used to induce experimental hyperthyroidism. Eltroxin was dissolved in distilled water. Each rat received daily $600 \mu \mathrm{g} / \mathrm{kg} /$ day of Elroxine for three successive weeks via oral gavage feeding needle ${ }^{[4]}$.

Group III (hypothyroid group): Rats used to induce experimental hypothyroidism. Neomercazole was dissolved in distilled water. Each rat received a daily 1.35 $\mathrm{mg} / \mathrm{kg} /$ day of Neomercazole for three successive weeks via oral gavage feeding needle ${ }^{[4]}$.

At the time of sacrifice (day 22), the animals were weighed then anesthetized by ether inhalation. Blood samples from rats' orbital veins of all groups were collected.

Right, and left parotid glands were removed through a transverse incision in the upper part of the neck. The skin was reflected from one side of the face to reveal this gland. The parotid salivary gland is located on the lateral side of the submandibular salivary gland below the ear; it is easily identified because it is irregular in shape and loosely organized.

The glands were weighted by using a portable mini digital LCD electronic scale.

\section{Biochemical (Hormonal) Analysis}

At the time of sacrifice, blood from each animal was rapidly collected from orbital vein transferred to centrifuge tubes without anticoagulant, and serum was separated by 
low-speed centrifugation (1500 xg $51 \mathrm{~min})$. The serum samples were stored at $-20^{\circ} \mathrm{C}$ until the analysis time. Serum thyroid hormones (total T3, total T4), thyroidstimulating hormone (TSH) and serum amylase levels were measured by in vitro diagnostic radioimmunoassay with the immunolite 2000 analyzer for the quantitative measurement ${ }^{[23]}$ at Tumor Markers Oncology Research center, Al-Azhar University.

\section{Histological Study}

The parotid glands were fixed in $10 \%$ formalin. The specimens were dehydrated in different grads of ethanol and then fixed to form paraffin blocks. The blocks were trimmed and cut into 5 - $\mu \mathrm{m}$ thick sections. Sections were stained with Haematoxylin and Eosin $(\mathrm{H} \& \mathrm{E})$ for routine histological study. Toluidine blue staining technique was used for the mast cells examination ${ }^{[24]}$. Sections were examined with the light microscope and photographed with the Lecia ICC50 W camera.

\section{Immunohistochemical Study (Bcl-2)}

Immunohistochemical reactions were carried out using the avidin-biotin-peroxidase system for localization of Bcl-2 (antiapoptotic marker). Paraffin sections were cut and deparaffinized in xylene for 30 minutes and re-hydrated. The endogenous peroxidase activity was blocked, rinsed in distilled water and then washed by phosphate-buffered saline (PBS). The PH should be 7.2. Slides were then dried, covered by protein blocking reagent (normal rabbit serum) followed by covering with the primary antibody, then the section was covered with biotinylated secondary anti-mouse antibody washed in PBS. Avidin biotin reagent (ABR) was prepared, slides were dried then were taken to distilled water, counterstained with Mayer's Haematoxylin, washed, dehydrated, left to dry, mounted, covered with glass covers and then examined. The positive results were indicated by brown coloration ${ }^{[7]}$. All stained sections were examined with the light microscope and photographed with the Lecia ICC50 W camera.

\section{Semithin Microscopic Study}

Specimens were cut into $1 \mathrm{~mm}$ cubes and fixed overnight in $2.5 \%$ phosphate-buffered glutaraldehyde $(\mathrm{pH} 7.3)$ at $4{ }^{\circ} \mathrm{C}$. Postfixation in $1 \%$ buffered osmium tetroxide for (1-2) hours was followed by graded alcohol dehydration, cleared in propylene oxide, and then embedded in fresh Epon capsules. Semithin sections were cut $(1 \mu \mathrm{m})$ and stained with toluidine blue ${ }^{[25]}$ and then examined with the light microscope and photographed with Lecia ICC50 W camera.

\section{Transmission Electron Microscopic Study}

Ultra-thin sections $(70-80 \mu \mathrm{m})$ were cut and mounted on copper grids. The grids were stained with uranyl acetate and lead citrate ${ }^{[26,27]}$ for examination with the transmission electron microscope (Jeol JEM. 1010) at Al-Azhar University, Regional Center for Mycology and Biotechnology.

\section{Morphometric Study}

Using Leica morphometric system (Leica Q500 MC, Wetzlar, Germany), image analysis system connected to an Olympus microscope (model BX51, Olympus Japan) with a digital camera for histological grading at (magnification $\mathrm{X} 200$ ), six non overlapping fields in six sections obtained from different animals from the same group were used for measuring.

The number of mast cells was counted in toluidine blue sections and Bcl-2 positive cells in Immunohistochemical sections then the average number was taken in each group.

\section{Statistical Analysis}

The biochemical analysis obtained (serum total T3, serum total T4, serum TSH), the number of the mast cell, parotid gland weight, and body weight were recorded and subjected to statistical analyzed. Data were expressed as mean and standard deviation (SD) for the quantitative variable. Data were statistically analyzed using statistical package SPSS version 16 (SPSS Inc., Chicago, USA). Comparisons between groups were done using ANOVA (analysis of variance) followed by post hoc test for multiple comparisons between every 2 groups. The results were considered significant when $p$-value $<0.05$ and highly significant when $p$-value $<0.001$.

\section{RESULTS}

During the period of the study, no signs of morbidity or mortality were recorded in the experimental animals. Moreover, no statistically significant difference detected in the biochemical, histological, Immunohistochemical and ultrastructure results were noticed between the subgroups of the control group (i, ii). So, they were mentioned in the study as a group I (Euothyroid).

\section{Parotid gland Weight}

The weight of the parotid gland was recorded (Table 1)

Gland weight in group I (Euothyroid) was $0.11 \pm 0.01$ gm $($ mean \pm SD). In group II (Hyperthyroidism), it was $0.062 \pm 0.01 \mathrm{gm}$. It showed a highly statistically significant decrease when compared to group I $(P<0.001)$. In group III (Hypothyroidism), it was $0.085 \pm 0.01 \mathrm{gm}$ where it showed a statistically significant decrease when compared to group I $(P<0.05)$ (Histogram 1).

\section{Rat's Body Weight}

The body weight of each rat was recorded at the start and on alternate days until the end of experiments. At the beginning of the experiment mean body weight in all animal's group was practically equal to $262.15 \pm 1.53$ (Table 2).

At the end of the experiment rat's weight from group II (Hyperthyroidism) was $254.1 \pm 3.77$. It showed a nonstatistically significant decrease than group I $(P>0.05)$. But in group III (Hypothyroidism) body weight was $251.25 \pm 7.27$ where it showed a statistically significant decrease than group I $(P<0.05)$ (Histogram 2$)$. 


\section{Biochemical Results}

\section{Serum Total T3}

In group I (Euothyroid), serum T3 was $4.52 \pm 0.28$ $\mathrm{ng} / \mathrm{dl}$ (mean $\pm \mathrm{SD}$ ). In group II (Hyperthyroidism), it was $6.12 \pm 0.51 \mathrm{ng} / \mathrm{dl}$. It showed a highly statistically significant increase when compared to group I $(P<0.001)$. In group III (Hypothyroidism), it was $3.27 \pm 0.58 \mathrm{ng} / \mathrm{dl}$ where it showed a statistically significant decrease when compared to group I $(P<0.05)$ (Table 3 and Histogram 3A).

\section{Serum Total T4}

Serum T4 in group I (Euothyroid), was $5.28 \pm 0.15 \mu \mathrm{g} /$ dl (mean \pm SD). In group II (Hyperthyroidism), it was $7.88 \pm 0.65 \mu \mathrm{g} / \mathrm{dl}$. It showed a highly statistically significant increase when compared to group I $(P<0.001)$. In group III (Hypothyroidism), it was $4.05 \pm 0.26 \mu \mathrm{g} / \mathrm{dl}$ where it showed a highly statistically significant decrease when compared to group I $(P<0.001)$ (Table 3 and Histogram 3B).

\section{Serum TSH}

In group I (Euothyroid), serum TSH was $2.31 \pm 0.47$ $\mu \mathrm{IU} / \mathrm{ml}$ (mean $\pm \mathrm{SD}$ ). In group II (Hyperthyroidism), it was $0.022 \pm 0.01 \mu \mathrm{IU} / \mathrm{ml}$. It showed a highly statistically significant decrease when compared to group I $(P<0.001)$. In group III (Hypothyroidism), it was $9.83 \pm 1.25 \mu \mathrm{IU} /$ $\mathrm{ml}$ where it showed a highly statistically significant increase when compared to group I $(P<0.001)$ (Table 3 and Histogram 3C).

\section{Serum Amylase}

Serum amylase in group I (Euothyroid), was $68.51 \pm 2.06$ $\mathrm{U} / \mathrm{L}$ (mean $\pm \mathrm{SD}$ ). In group II (Hyperthyroidism), it was $124.36 \pm 11.55 \mathrm{U} / \mathrm{L}$. It showed a highly statistically significant increase when compared to group I $(P<0.001)$. In group III (Hypothyroidism), it was $42.24 \pm 6.75$ U/L where it showed a highly statistically significant decrease when compared to group I $(P<0.001)$ (Table 3 and Histogram 3D).

\section{Histological Results}

Examination of hematoxylin and eosin (Hx\&E) stained sections of the parotid gland obtained from the group I (Euothyroid group) showed that the parotid gland was formed of lobules, each lobule contained regular serous acini and ducts with a fine network of interlobular connective tissue (Figure 1A). Each serous acinus consisted of a single layer of pyramidal cells with basal rounded nuclei surrounding a narrow lumen. Striated ducts appeared intervening between the acini, lined by a single layer of columnar epithelium (Figure 1B).

Examination of the Hx\&E stained sections of the parotid gland obtained from group II (hyperthyroid group) showed swollen serous acini, some acini appeared darkly stained and others appeared lightly stained (Figures 2A and 2B). Striated duct appeared dilated and lined by more than one layer of cells (Figure 2A). Lobules were separated by markedly congested blood vessels (Figures 2A and 2B). Mononuclear cellular infiltration was also observed (Figure 2B).

Examination of Hx\&E stained sections of the parotid gland obtained from group III (hypothyroid group) showed that the parenchyma contained widely separated serous acini some of the acini were opaque and others were pale and cloudy (Figures 3A and 3B). Some acinar cells had small deeply stained nuclei and highly vacuolated cytoplasm (Figure 3B). Interlobular ducts were dilated and lined by more than one layer (Figure 3A). A cellular infiltration (Figure 3A) and mildly congested blood vessels (Figures $3 \mathrm{~A}$ and $3 \mathrm{~B}$ ) in the interstitial space could be observed.

\section{Toluidine Blue Stained Results}

Histological examination of Toluidine blue sections of group I showed few mast cells detected (Figure 4A). In group II, showed abundant mast cells within the connective tissue between the acini (Figure 4B). In group III, showed some mast cells within the connective tissue between the acini (Figure 4C).

On the other hand, in a group, I (Euothyroid) number of mast cells was $2.2 \pm 0.92 / \mathrm{mm}^{3}$ (mean \pm SD). In group II (hyperthyroid), it was $8 \pm 3.7 / \mathrm{mm}^{3}$. It showed a highly statistically significant increase when compared to group I $(P<0.001)$. In group III (hypothyroid), it was $5.4 \pm 2.12 / \mathrm{mm}^{3}$ where it showed a highly statistically significant increase when compared to group I $(P<0.001)$ (Table 4, Histogram 4)

\section{Immunohistochemical Results}

Immunohistochemically stained sections of the parotid gland from the group I showed positive brown color immune reaction for bcl2 in the cytoplasm of parotid acinar cells (Figure 5A). In group II, showed moderate immune reaction for bcl 2 in the cytoplasm of parotid cells (Figure 5B). In group III showed a weak immune reaction for bcl2 in the cytoplasm of parotid cells (Figure 5C).

Moreover, in group, I (Euothyroid) number of Bcl-2 positive cells was $15.3 \pm 3.37$ (mean \pm SD). In group II (Hyperthyroidism), it was $10 \pm 2.83$. It showed a statistically significant decrease when compared to group I $(P<0.05)$. In group III (Hypothyroidism), it was 5.2 \pm 3.94 where it showed a highly statistically significant decrease when compared to group I $(P<0.001)$ (Table 5, Histogram 5).

\section{Semithin Results}

Examination of the semithin sections of group I showed that the pyramidal acinar cells were resting on a basement membrane and had vesicular nuclei. Binucleated cells were observed. The cytoplasm of the cells was filled with variable density secretory serous granules (Figure 6).

The examination of semithin sections of group II showed that the acinar cells contained basal nuclei and vacuoles. The cytoplasm of acinar cells contained granules 
some were electron-dense and others were of moderate density (Figures 7A and 7B). Intercalated duct appeared lined with a single layer of cells (Figure 7B). Congested blood vessels (Figure 7A) and inflammatory cells (Figure 7B) were observed.

Examination of the semithin sections of group III showed that some of the acinar cells had deeply stained nuclei (Figure 8A), while others had a ghost-like nucleus (Figures 8A and 8B) and few cells contained basal vesicular nuclei (Figure 8A). The cytoplasm of cells contained many vacuoles (Figure $8 \mathrm{~B}$ ) and secretory granules; some were electron-lucent (Figure 8A), others were electron-dense (Figure 8B). Striated ducts were lined with more than one layer (Figure 8A). Mildly congested blood vessels (Figure 8A) and cellular infiltration (Figure 8B) were observed in the interstitial tissue.

\section{Ultrathin Results}

Examination of the ultrathin sections of group I showed that parotid acinar cells had ovoid euchromatic nuclei with a peripheral thin rim of heterochromatin. The cytoplasm contained many membranes bounded electron-dense secretory granules (Figure 9).
Ultrathin sections of the hyperthyroid group (group II) showed that some of the acinar cells contained electronlucent secretory granules (Figure 10A), other cells contained electron-dense secretory granules (Figure 10B) and others were mixed (Figure 11). Acinar cells nuclei were irregular (Figures 10B and 11) and there was a rupture in the nuclear membrane (Figure 11). Their cytoplasm contained rough endoplasmic reticulum (Fig. 11). Few vacuoles were noticed in the cytoplasm (Figure 10A). Congested blood vessels (Figure 10A), collagen fibers and areas of degeneration (Figure 10B) were observed.

Ultrathin sections of the hypothyroid group (group III) showed irregular heterochromatic nuclei of acinar cells with the rupture of the nuclear membrane (Figure 12A), other cells contained small nuclei (Figure 12A). The cytoplasm contained electron-lucent secretory granules (Figures 12A and 12B) and variablesized vacuoles (Figure 12B) that encroached on the nucleus (Figure 12B). Some acinar cell's cytoplasm showed illdefined organelles (Figure 12A), others showed dilated rough endoplasmic reticulum (Figure 12B). Congested blood vessels in the interstitial space and collagen fibers (Figure 12B) were seen.
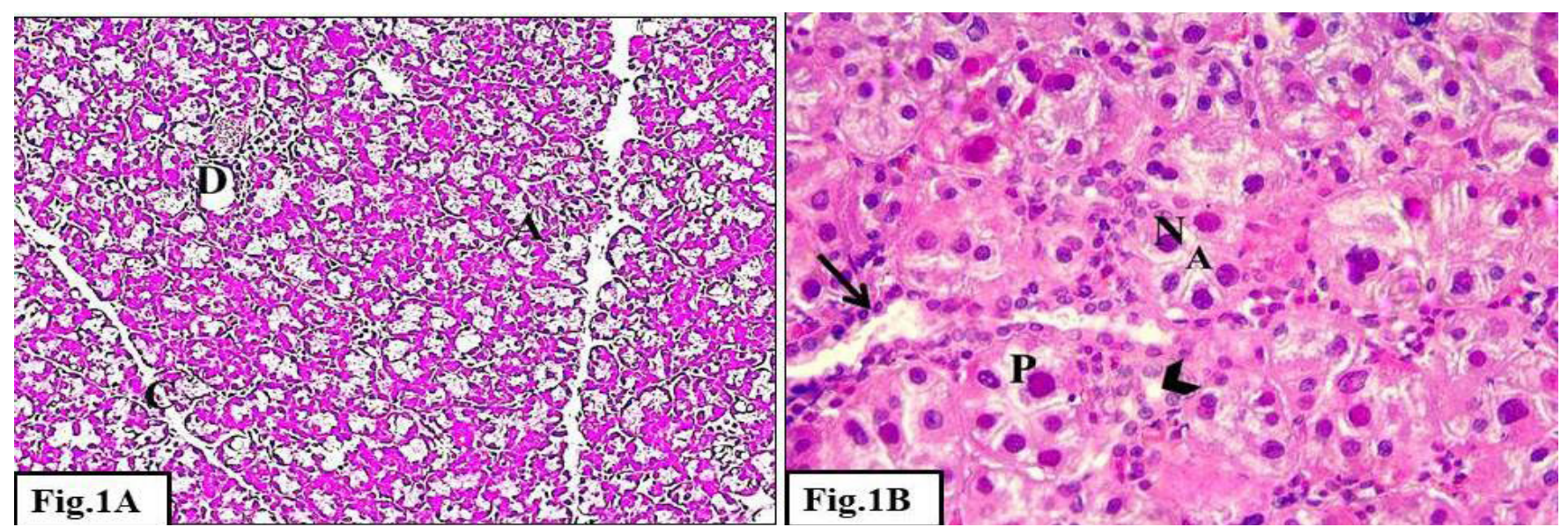

Fig. 1: Photomicrographs of sections of rat parotid gland from the control group (group I) (A) showing the lobules of the gland, each lobule is formed of serous acini (A) and ducts (D) with a fine network of interlobular connective tissue (C) (Hx. \&E.; X200). (B) Showing serous acini (A) consisted of a single layer of pyramidal cells $(\mathrm{P})$ with basal rounded nuclei $(\mathrm{N})$ surrounding a lumen (arrow head).Among the acini, Striated ducts are observed and lined by a single layer of columnar epithelium (arrow) (Hx. \&E.; X400).
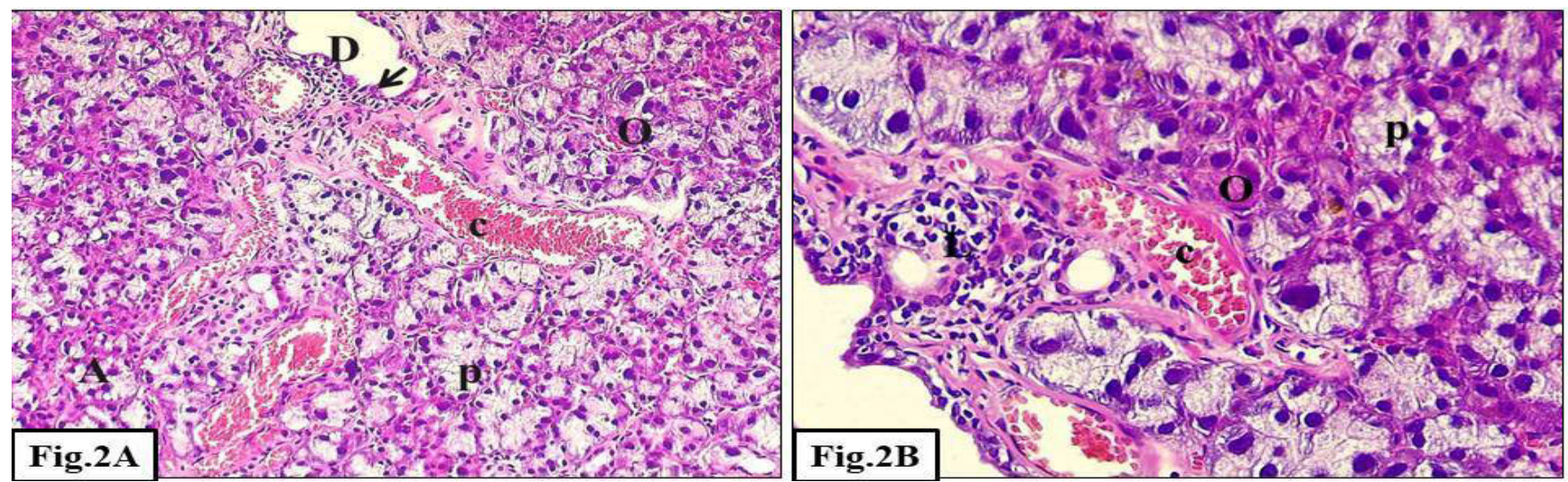

Fig. 2: Photomicrographs of sections of the parotid gland from the hyperthyroid group (group II) (A) showing mildly swollen serous acini (A), some acini appear lightly stained (P), others appear darkly stained (O). Striated duct appear dilated (D) and lined by more than one layer (arrow). Notice the marked congestion in the interlobular blood vessels (C) (Hx.\&E.; X200). (B) Showing lightly (P) and darkly stained (O) serous acini. Congested blood vessels (C) and cellular infiltration (L) are observed in the interstitial tissue (Hx\&E.; X400). 


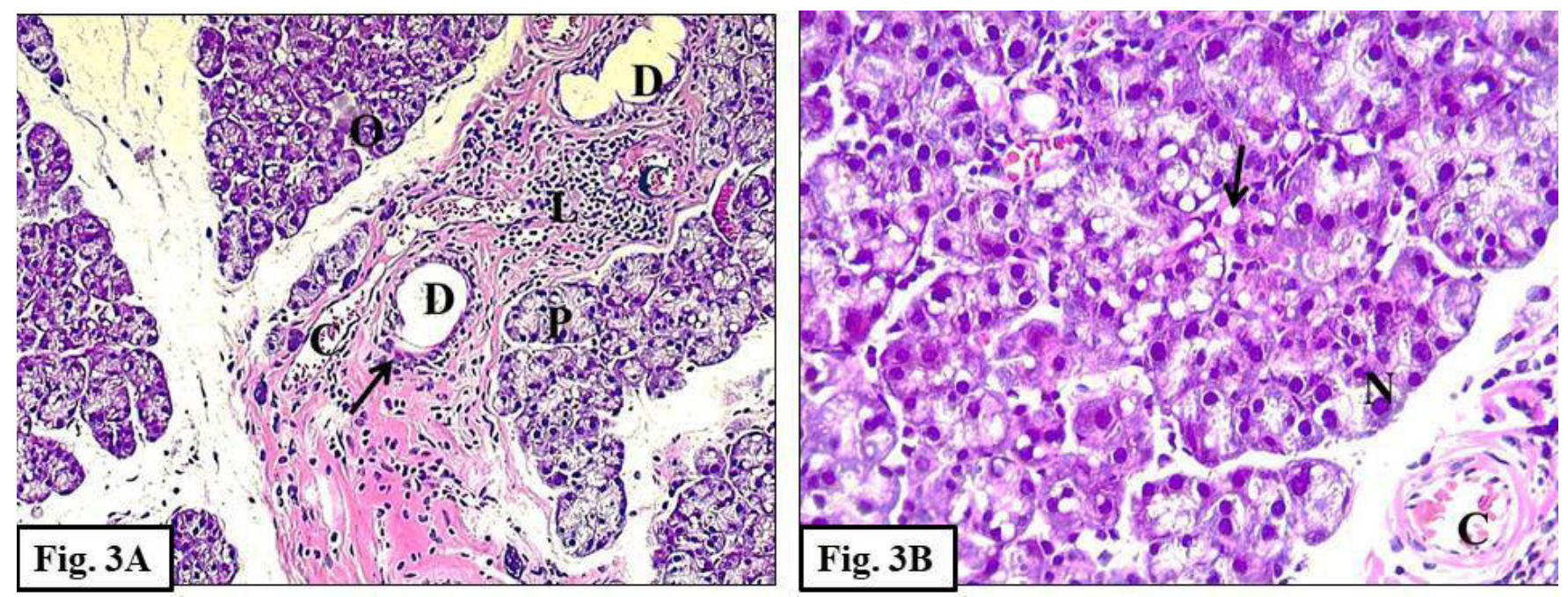

Fig. 3: Photomicrographs of parotid gland sections from the hypothyroid group (group III) (A) showing widely separated serous acini, some of the acini are darkly stained (O) and others are lightly stained (P). Interlobular ducts are dilated (D) and lined by more than one layer (arrow). Notice cellular infiltration (L) and mildly congested blood vessels (C) in the interstitial space (Hx.\&E.; X200). (B) Showing acinar cells with small deeply stained nuclei (N) and highly vacuolated cytoplasm (arrow). Mildly congested blood vessels (C) are observed (Hx.\&E.; X400).
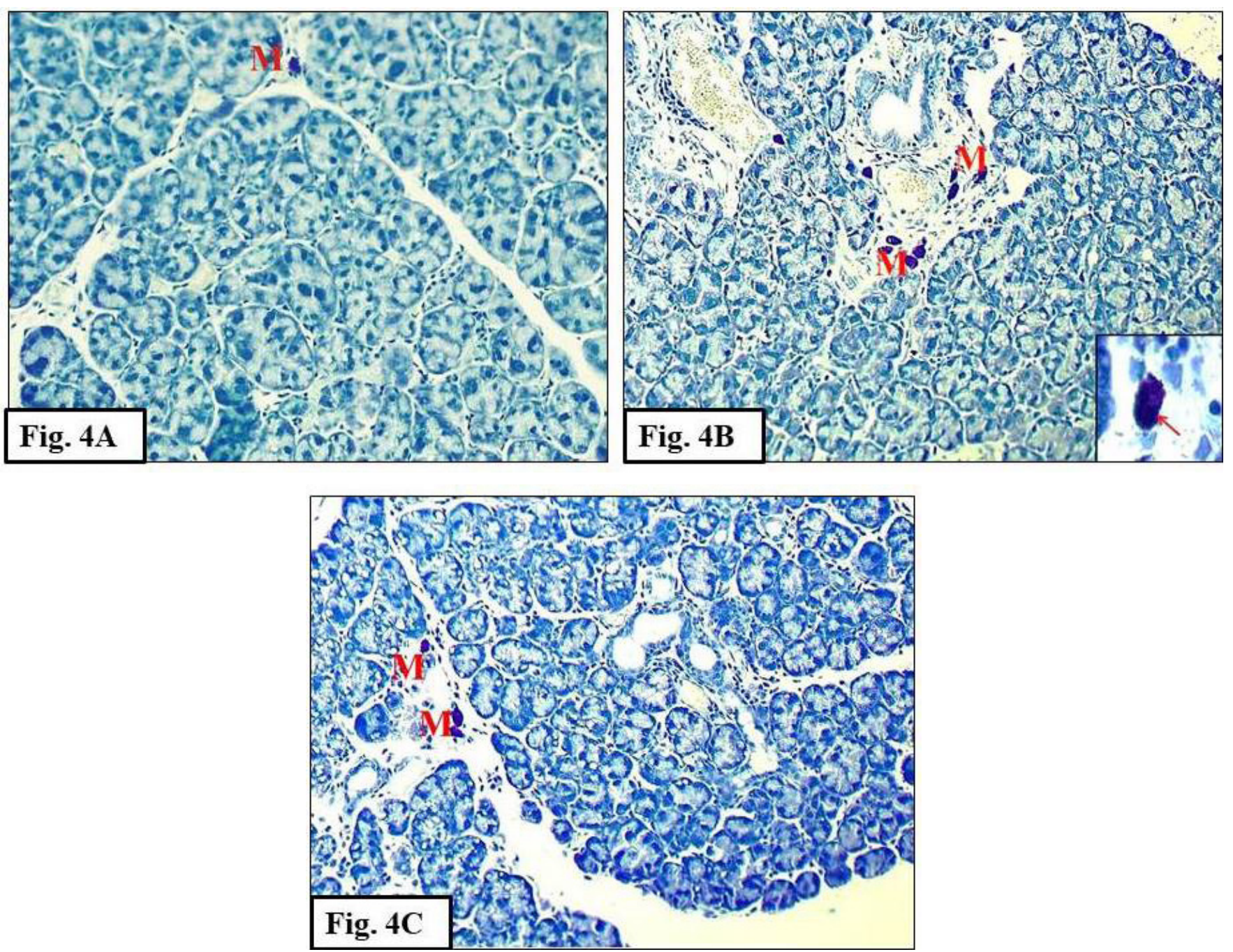

Fig. 4: Photomicrograph of sections of the rat parotid gland (A) from the control group showing few mast cells (M) (Toluidine blue; X200). (B) From the hyperthyroid group (group II) showing abundant mast cells (M) within the connective tissue (Toluidine blue; X200) Right inset x1000. (C) From the hypothyroid group (group III) showing some mast cells (M) within the connective tissue (Toluidine blue; X200). 

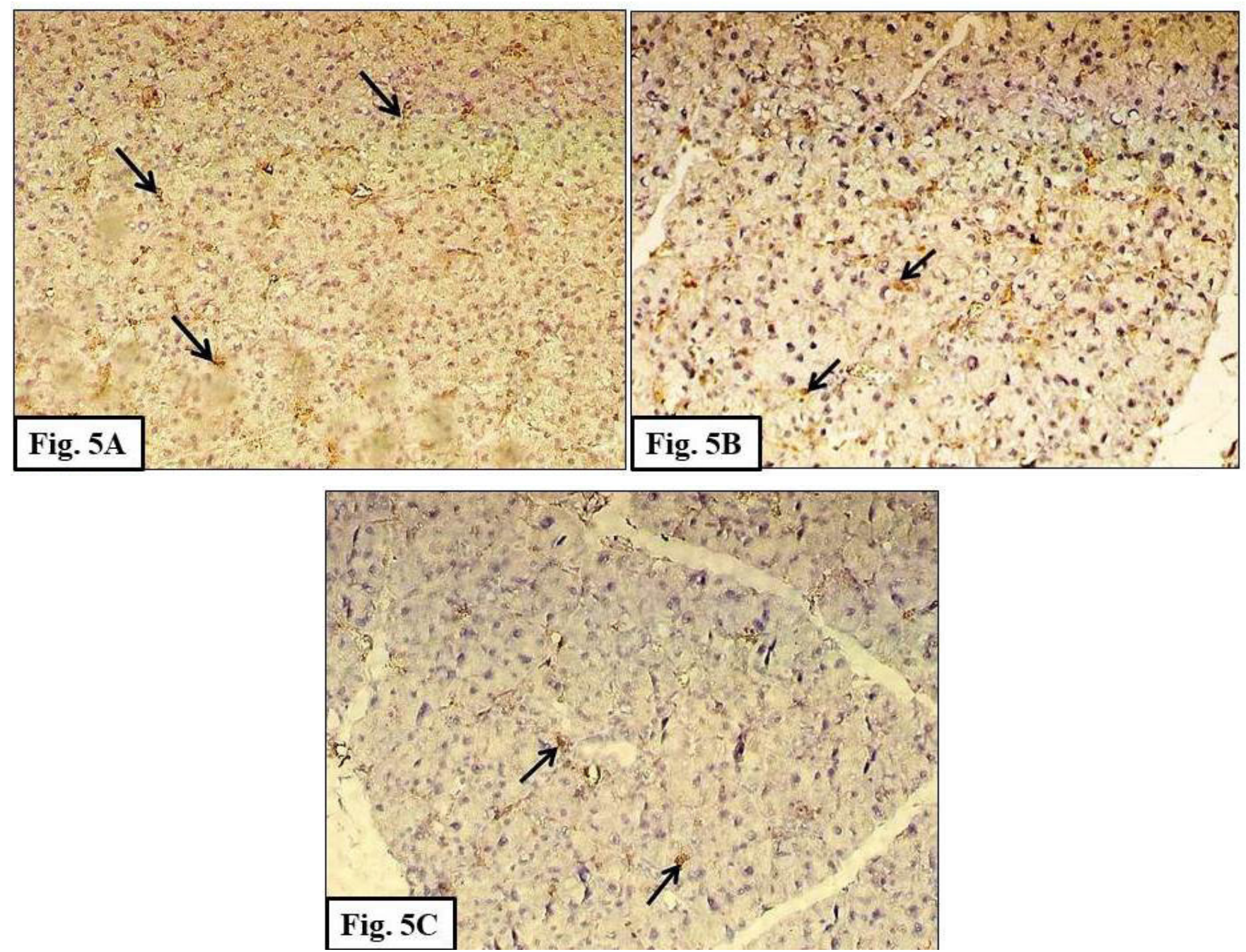

Fig. 5: Immunohistochemically stained sections of rat parotid gland (A) from the control group (group I) showing positive brown immune reaction for bcl2 (arrow) in the cytoplasm of parotid acinar cells (Bc12; X200). (B) From the hyperthyroid group (group II) showing moderate immune reaction for bcl2 (arrow) in the cytoplasm of parotid cells (Bcl2; X200). (C) From the hypothyroid group (group III) showing weak immune reaction for bcl2 (arrow) in the cytoplasm of parotid acinar cells (Bcl2; X200).

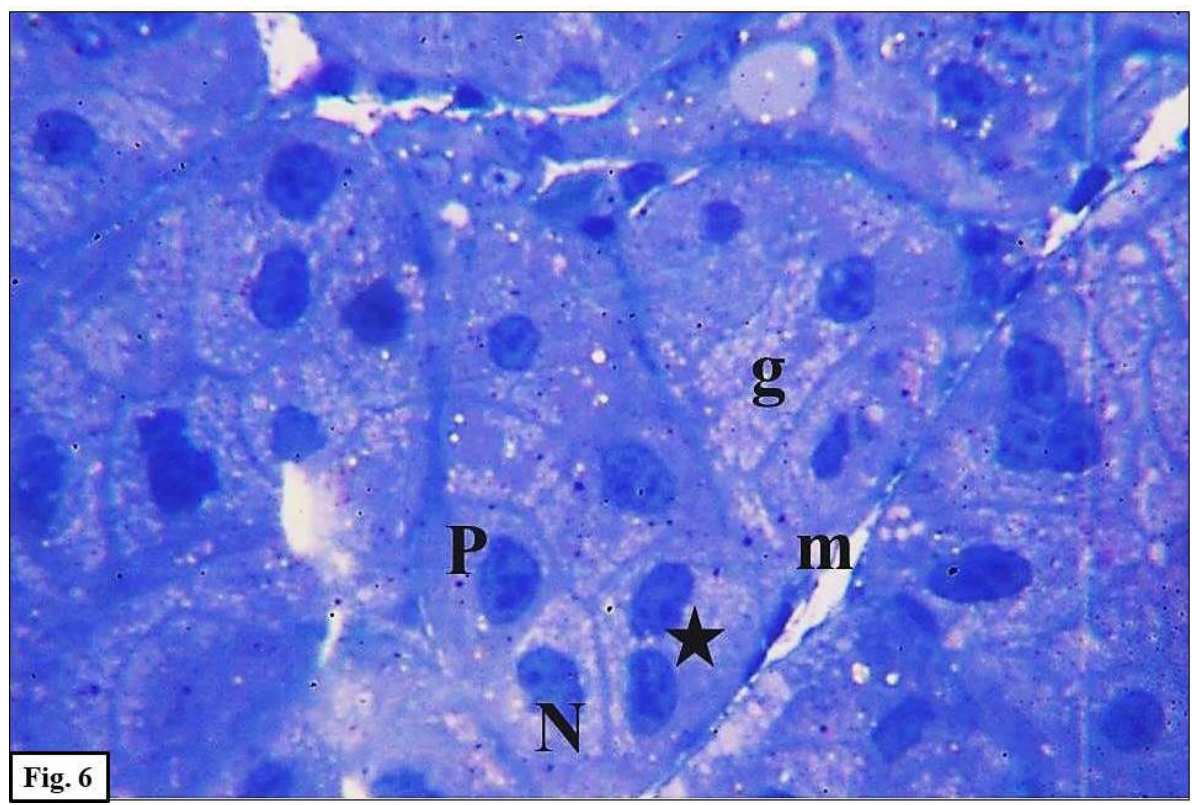

Fig. 6: A semithin section of rat parotid from the control group showing pyramidal acinar cells (P) rested on a basement membrane (m) and having vesicular nuclei $(\mathrm{N})$. The cytoplasm of the cells is filled with variable density secretory granules (g). Binucleated cells are observed (asterisk). (Toluidine blue; X1000) 

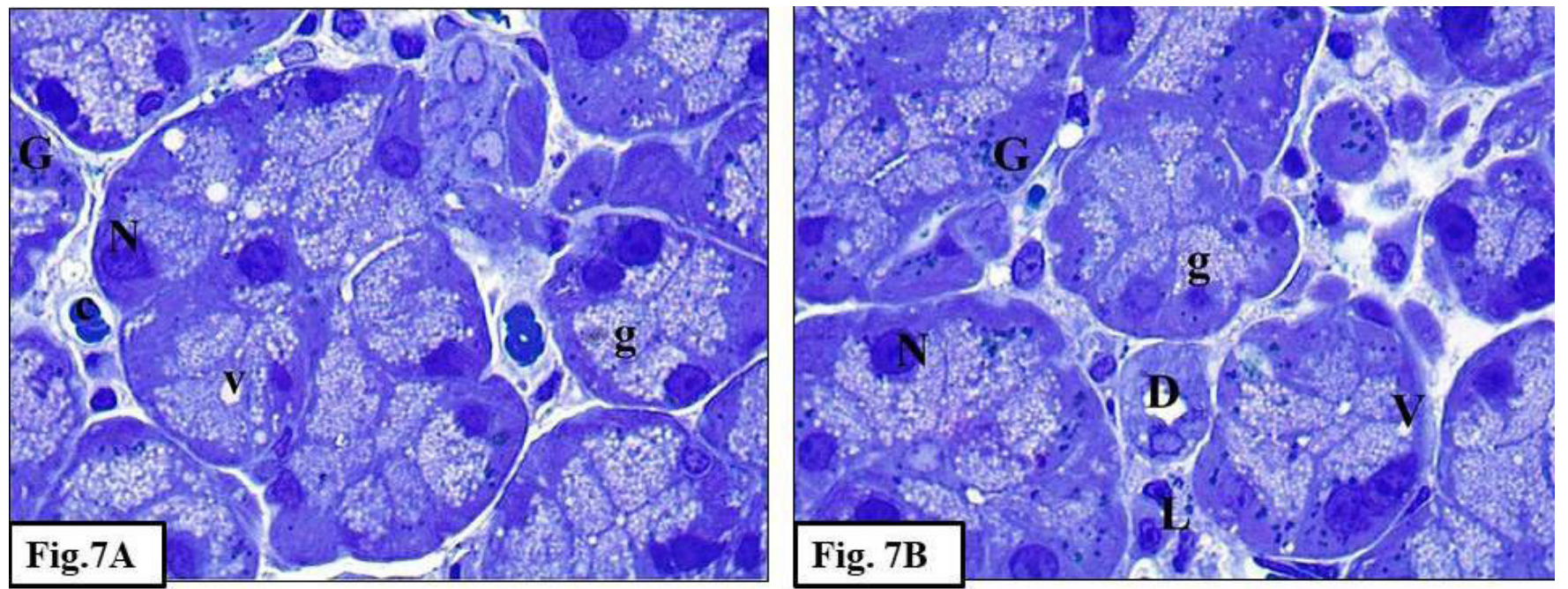

Fig. 7: Semithin sections of the parotid gland of the hyperthyroid group (group II) (A) showing acinar cells contained basal nuclei (N) and vacuoles (V). Many moderate density secretory granules (g) and few dark secretory granules $(\mathrm{G})$ are observed. Notice congested blood vessels (c) (Toluidine blue; X1000). (B) Showing acinar cells with basal nuclei $(\mathrm{N})$ and granular cytoplasm with variable density secretory granules some are dark (G), others are moderate density (g). Intercalated duct (D) is lined with a single layer. Few vacuoles (V) and inflammatory cells (L) are observed (Toluidine blue; X1000).
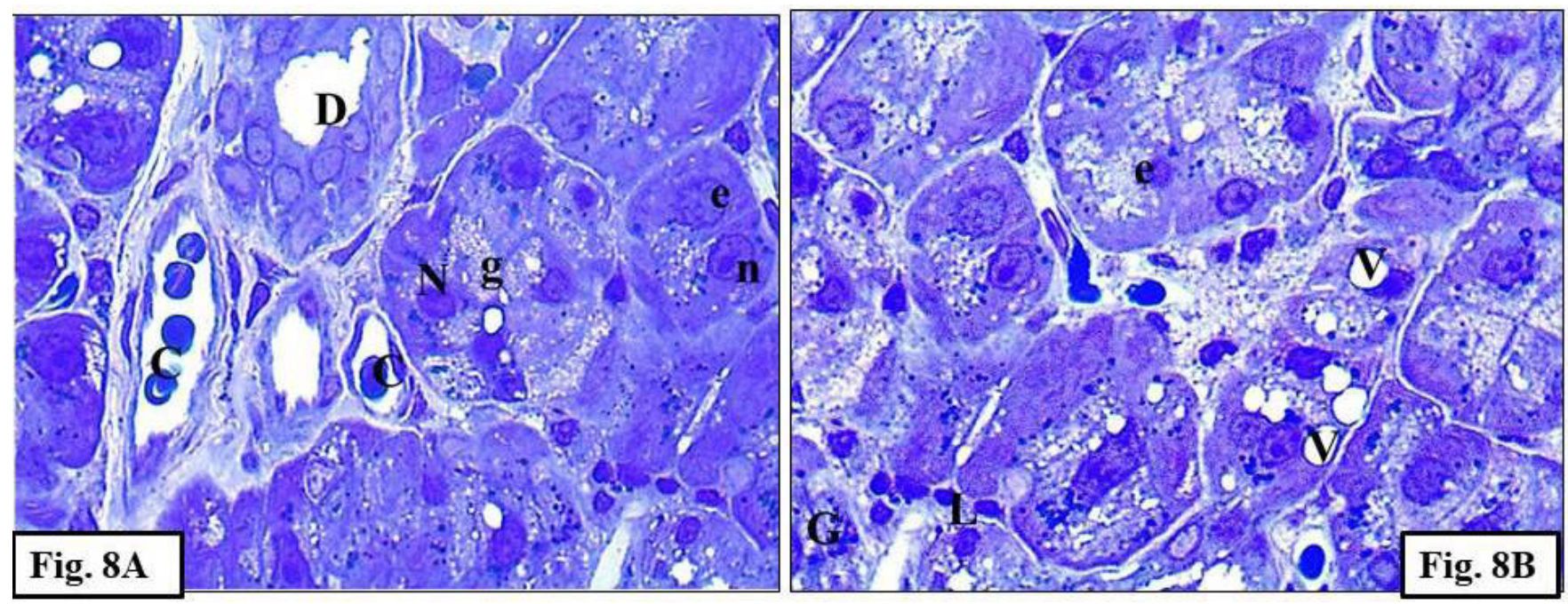

Fig. 8: Semithin sections of the parotid gland from the hypothyroid group (group III) (A) showing acinar cells, some of them have deeply stained nuclei (N), others have a ghost-like nucleus (e) and few cells contain basal vesicular nuclei (n). Striated ducts (D) are lined with more than one layer. Some secretory granules (g) and mildly congested blood vessels (C) are observed (Toluidine blue; X1000). (B) Showing disturbed acinar cells some cells have ghost nuclei (e). The cytoplasm of the cells has many vacuoles (V) and some secretory dense serous granules (G). A cellular infiltration (L) appears in the interstitial tissue (Toluidine blue; X1000)

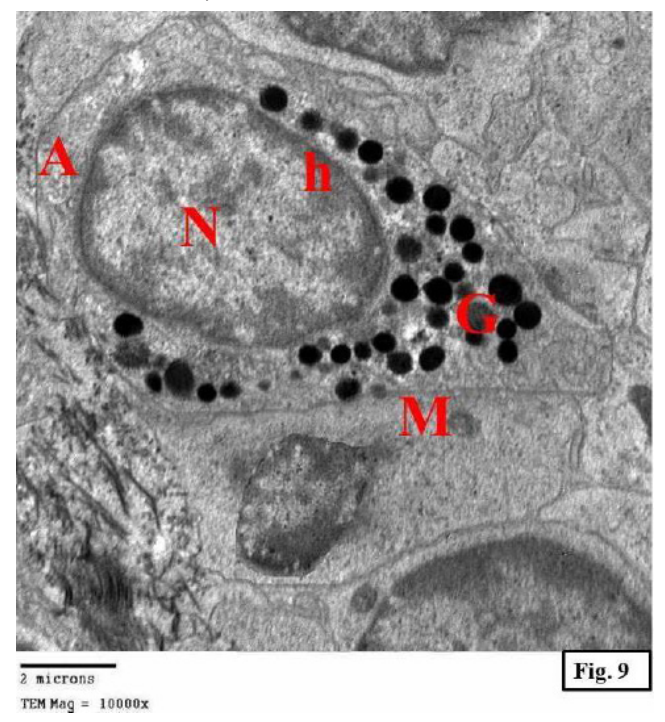

Fig. 9: Transmission electron micrograph of a section of rat parotid gland from the control group (group I) showing serous acinar cell (A) with ovoid euchromatic nucleus $(\mathrm{N})$ with a peripheral thin rim of heterochromatin (h). Notice the mitochondria (M) and the membrane-bounded electrondense secretory granules $(\mathrm{G})$ in the cytoplasm. (Uranyl acetate and lead citrate X 10000) 

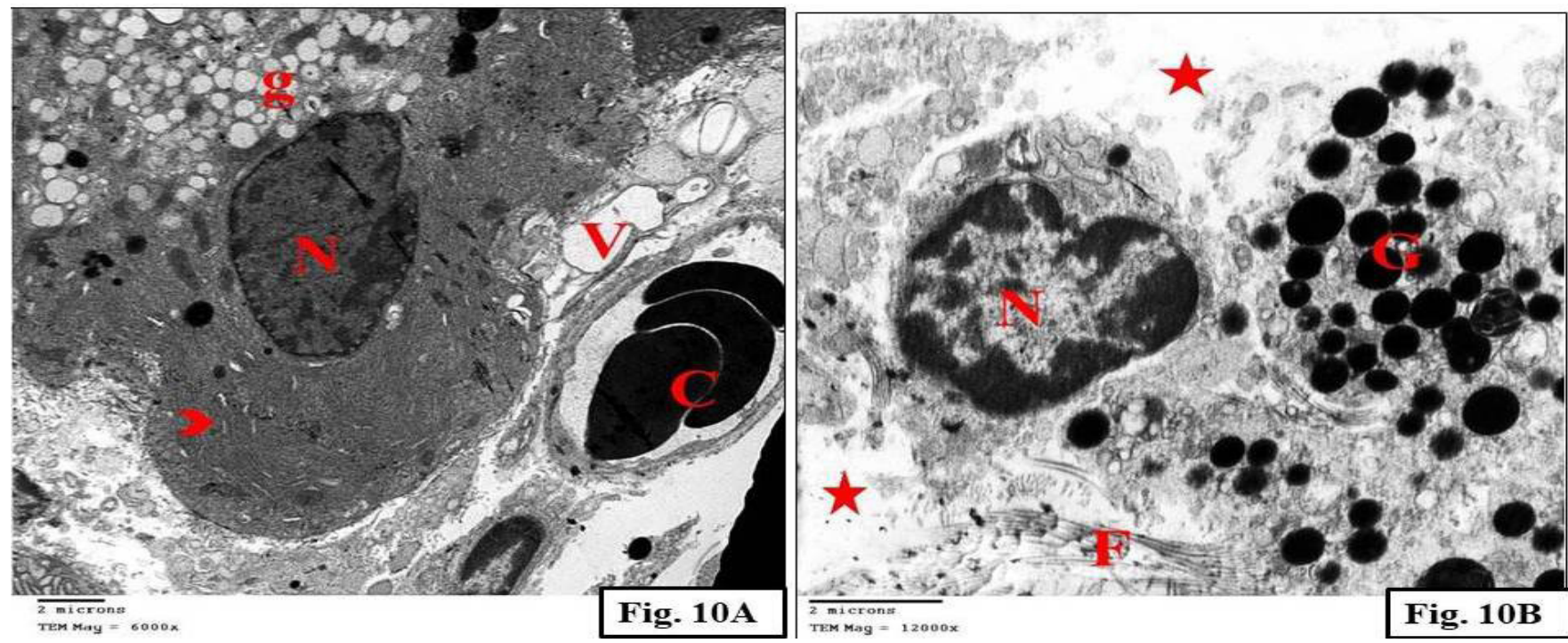

Fig. 10: Transmission electron micrograph of parotid gland section from the hyperthyroid group (group II) (A) showing acinar cell containing a more or less normal nucleus (N) surrounded by cytoplasm with ill-defined organelles (arrow head). Vacuoles (V), electron-lucent granules (g) and congested blood vessels (C) in the interstitial tissue are observed. (Uranyl acetate and lead citrate X 6000) (B) Showing other acinar cells with irregular nuclei (N) and electron-dense secretory granules $(\mathrm{G})$ in the cytoplasm. Collagen fibers (F) and areas of degeneration (asterisk) are observed. (Uranyl acetate and lead citrate X 12000)

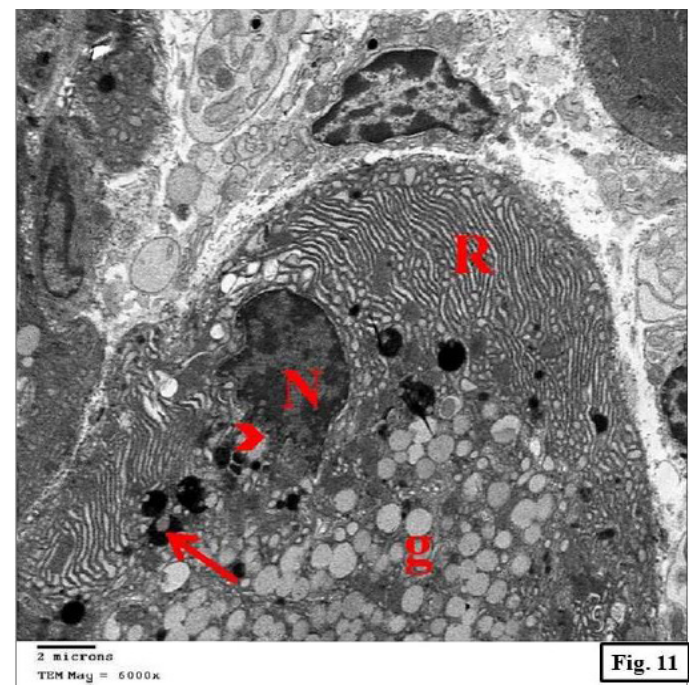

Fig. 11: Transmission electron micrograph of parotid gland section from the hyperthyroid group (group II) showing an irregular acinar cell nucleus (N) with the irregular nuclear membrane (arrow head). The cytoplasm containing many membrane-bounded electron-lucent secretory granules (g) and rough endoplasmic reticulum $(\mathrm{R})$.Some granules are mixed electron-dense with electro-lucent (arrow). (Uranyl acetate and lead citrate X 6000)
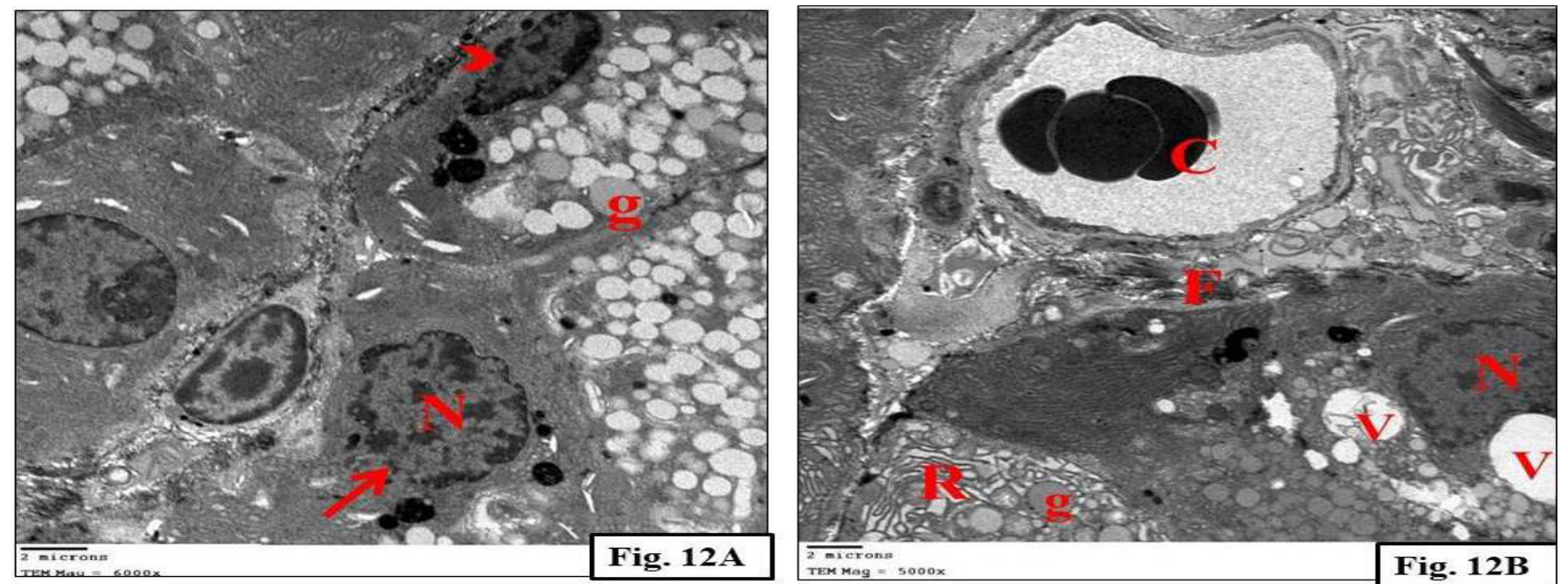

Fig. 12: Transmission electron micrograph of a section of the parotid gland from the hypothyroid group (group III) (A) showing acinar cell with irregular heterochromatic nuclei $(\mathrm{N})$ with rupture of the nuclear membrane (arrow).The cytoplasm contain few electron-lucent secretory granules (g). Small nuclei (arrow head) are observed. (Uranyl acetate and lead citrate X 6000) (B) Showing increase vacuolation (V) that encroach on the nucleus of the acinar cell (N). Congested blood vessels (C) in the interstitial space and dilated rough endoplasmic reticulum (R) are observed in the cytoplasm of the acini. Many electronlucent secretory granules (g) and collagen fibers (F) are seen. (Uranyl acetate and lead citrate X 5000). 
Table 1: Mean weight of parotid gland (gm) in groups I, II, III (Mean \pm SD)

\begin{tabular}{lccc}
\hline Parameter & Group I & Group II & Group III \\
\hline Parotid gland weight $(\mathrm{gm})$ & $0.11 \pm 0.01$ & $0.062 \pm 0.01^{* *}$ & $0.085 \pm 0.01^{*}$ \\
\hline
\end{tabular}

Table 2: Mean rat's body weight $(\mathrm{gm})$ in groups I, II, III (Mean $\pm \mathrm{SD})$

\begin{tabular}{lccc}
\hline Parameter & Group I & Group II & Group III \\
\hline Bodyweight $(\mathrm{gm})$ & $262.15 \pm 1.53$ & $254.1 \pm 3.77$ & $251.25 \pm 7.27^{*}$ \\
\hline
\end{tabular}

Table 3: Serum concentration of T3, T4, TSH and serum amylase in control, hyperthyroid and hypothyroid groups

\begin{tabular}{lccc}
\hline Parameter & T3 (ng/dl) & T4 $(\mu \mathrm{g} / \mathrm{dl})$ & TSH $(\mu \mathrm{IU} / \mathrm{ml})$ \\
\hline GI (Euothyroid) & $4.52 \pm 0.28$ & $5.28 \pm 0.15$ & $2.31 \pm 0.47$ \\
GII (Hyperthyroid) & $6.12 \pm 0.51^{* *}$ & $7.88 \pm 0.65^{* *}$ & $0.022 \pm 0.01^{* *}$ \\
GIII (Hypothyroid) & $3.27 \pm 0.58^{*}$ & $4.05 \pm 0.26^{* *}$ & $9.83 \pm 1.25^{* *}$ \\
\hline
\end{tabular}

Table 4: Table 4: Mean number of mast cells in parotid gland in group I, II, III (Mean \pm SD)

\begin{tabular}{lccc}
\hline Parameter & Group I & Group II & Group III \\
\hline Mast cell in parotid gland $\left(\right.$ number $\left./ \mathrm{mm}^{3}\right)$ & $2.2 \pm 0.92$ & $8 \pm 3.7^{* *}$ & $5.4 \pm 2.12^{* *}$ \\
\hline
\end{tabular}

Table 5: Mean number of Bcl-2 positive cells in parotid gland in group I, II, III (Mean \pm SD)

\begin{tabular}{llll}
\hline Parameter & Group I & Group II & Group III \\
\hline Bcl-2 positive cells & $15.3 \pm 3.37$ & $10 \pm 2.83^{*}$ & $5.2 \pm 3.94^{* *}$ \\
\hline
\end{tabular}

Data in tables $(1,2,3,4,5)$ are presented as mean $\pm \mathrm{SD}$, mean and analyzed by one-way analysis of variance followed by Bonferroni's multiple comparison test (post-test); $P \leq 0.05$ was considered statistically significant in all analyses and $P<0.001$ was considered highly statistically significant.

- * = statistically significant difference from the group I

-**= highly statistically significant difference from the group I.

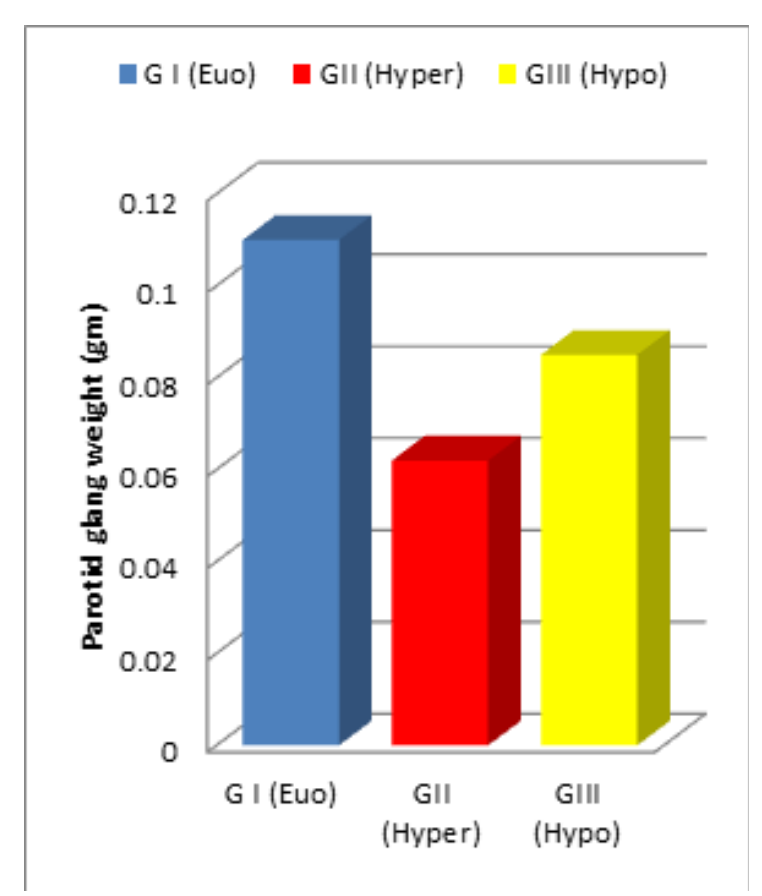

Histogram 1: Mean total Parotid gland weight changes in the examined group

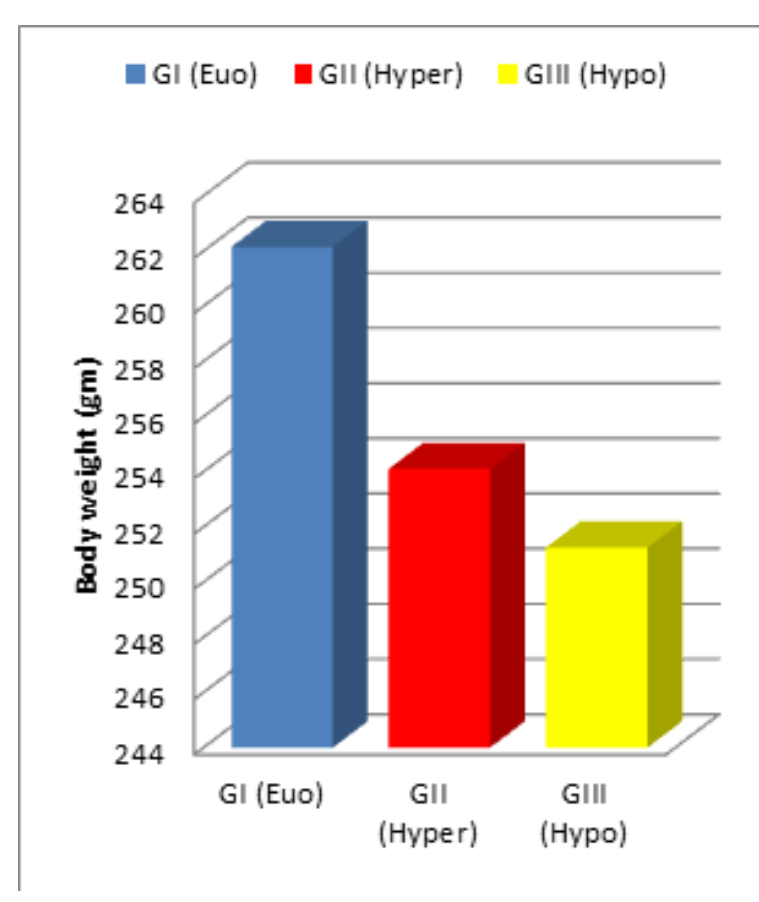

Histogram 2: Mean total bodyweight changes in the examined group 


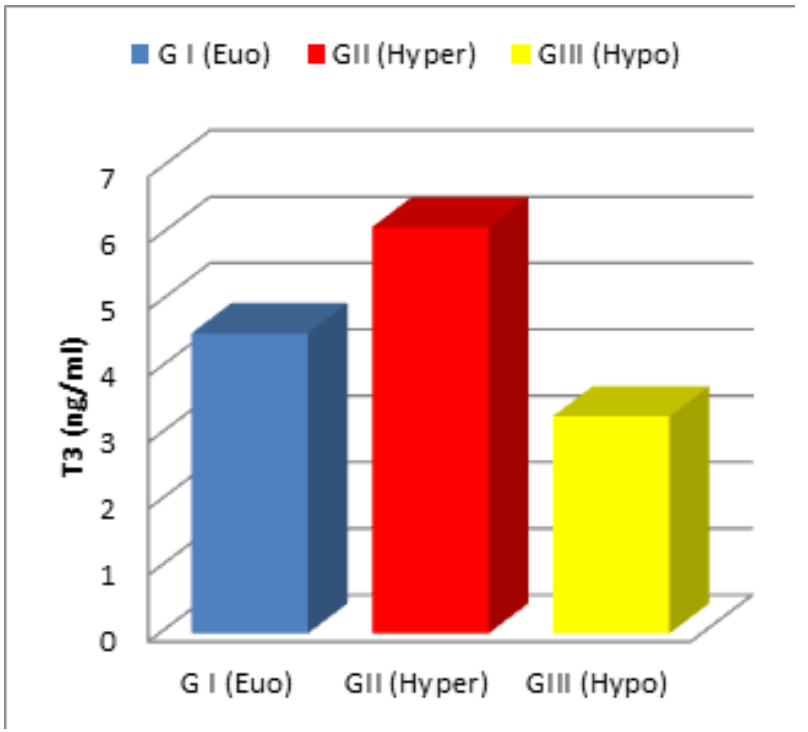

A: Changes in serumT3 levels in different groups

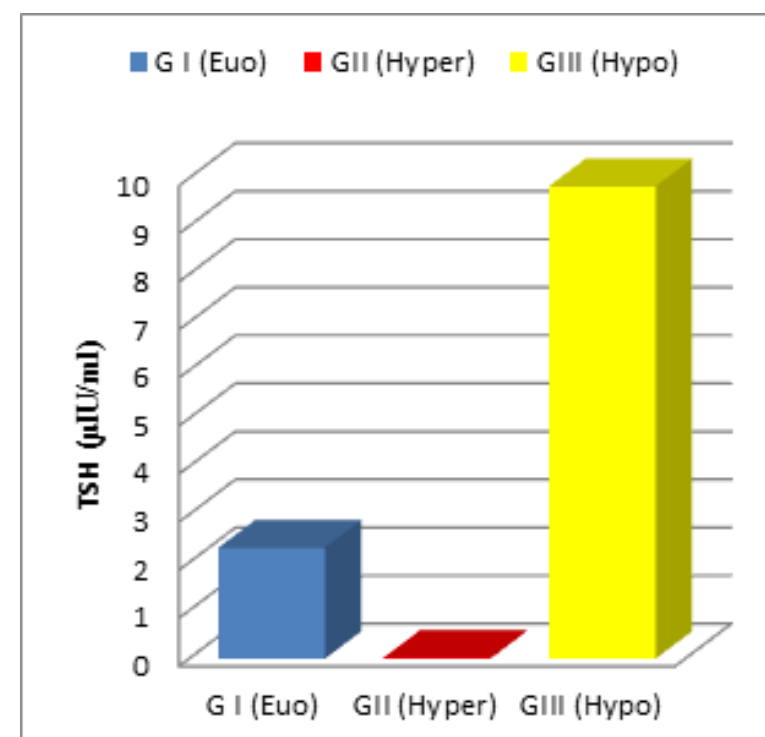

$\mathrm{C}$ : Changes in the serum TSH level in different groups

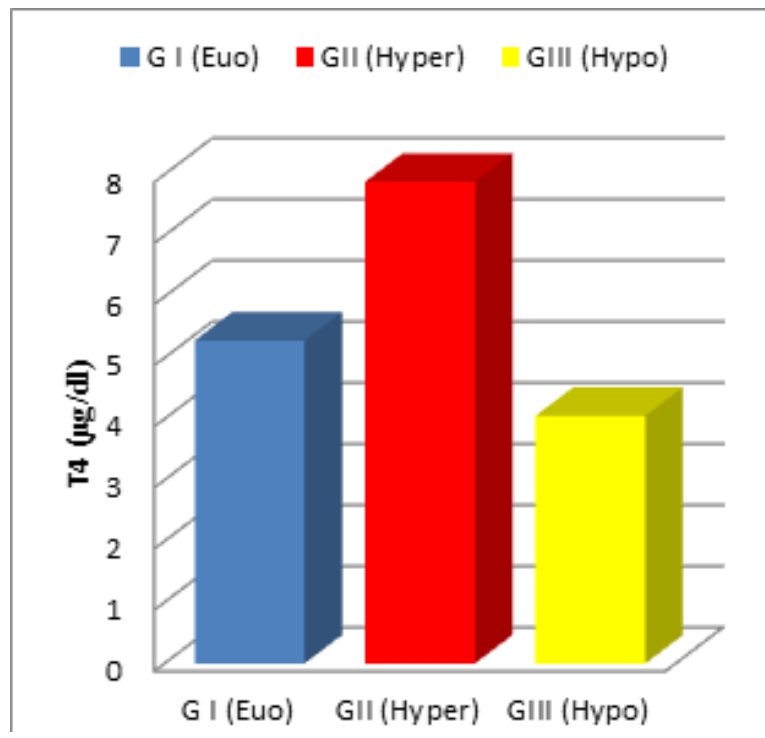

B: Changes in serumT4 levels in different groups

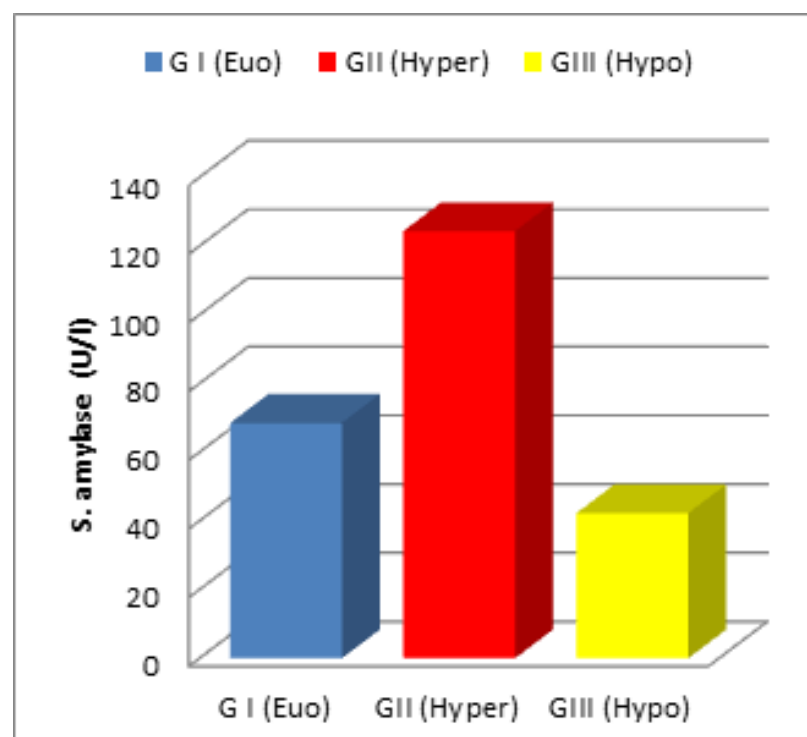

D: Changes in serum amylase levels in different groups

Histogram 3: A significant changes in the serum T3 (A), serum T4 (B), serum TSH (C) and serum amylase (D)

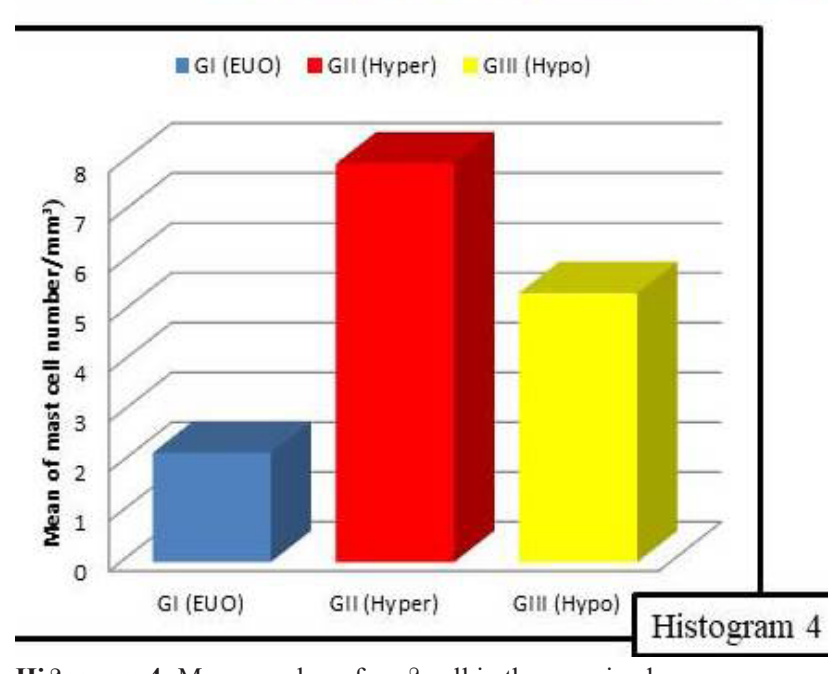

Histogram 4: Mean number of mast cell in the examined group

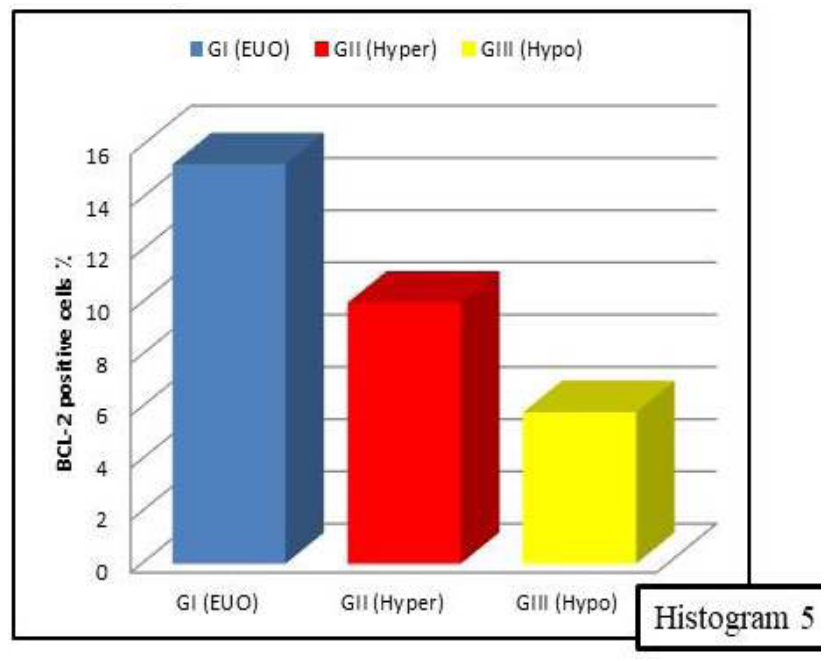

Histogram 5: Mean number of BCL-2 positive cells in the examined group 


\section{DISCUSSION}

In the present study, the development of Thyroid dysfunction was documented biochemically and statistically. In the hyperthyroid group, a highly significant increase was observed in total serum T3, T4 with a highly significant decrease in TSH. While in the hypothyroid group, a significant decrease in T3, a highly significant decrease in T4, with a highly significant increase in TSH were observed. These changes were in agreement with Abd elazeem et al. $(2016)^{[7]}$. who mentioned that experimental hypothyroidism was accompanied by a significant decrease in T3, T4 and an increase in TSH serum level. Moreover, Kandir and Keskin (2016) mentioned that alterations in T4 and TSH serum level have been shown the same results of the present study and that means that hyperthyroidism and hypothyroidism were well established experimentally ${ }^{[2]}$.

Also, parotid dysfunction was documented biochemically and statistically. In hyperthyroidism serum amylase showed a highly statistically significant increase and in hypothyroidism serum amylase showed a highly statistically significant decrease. These were in agreement with Tachibana and Hagino (1982) who mentioned that the contents of serum amylase proteins decreased in the hypothyroid status ${ }^{[28]}$.

Hyperthyroid rats showed an insignificant decrease in body weight while hypothyroid rats showed a significant decrease in body weight. This was in accordance with Hashem et al. (2016) who stated that a decrease in body weight gain was noticed in both hyper and hypothyroid rats $^{[4]}$. Ajayi et al. (2013) added that hyperthyroidism caused a reduction in body weight gain due to increased metabolic rate, energy expenditure and decrease in adipose tissue $^{[29,30]}$.

A statistically significant decrease in parotid gland weight was observed in the present study in both hyperthyroidism and hypothyroidism. Hayat et al. (2010) noticed in hypothyroid state the same changes in the gland weight and explained that by decreased cellular activity and degenerative changes in acini ${ }^{[13]}$.

Examination of the parotid of H\&E stained sections in hyperthyroidism showed some irregular acini while hypothyroidism showed many irregular serous acini. The same result was obtained by Hayat et al. (2010) who observed acini with indistinct outlines in hypothyroid rats $^{[13]}$. Bano et al. (2018) added that on giving exogenous T3 for developing rats, regular acini in salivary glands were observed. Also in hypothyroid rats acini were widely separated ${ }^{[31]}$. This was clarified by Oncu et al. $(2004)^{[24]}$ who observed atrophy of acini and Hayat et al. (2010) who declared an increase in the amount of inter acinar \& interlobular connective tissue in hypothyroidism ${ }^{[13,24]}$.

Intense vacuolation was observed in semithin sections of hypothyroid glands but mild vacuolation was observed in hyperthyroid rats. This was in accordance with Abd Elazeem et al. (2016) who observed irregular parotid acini with vacuolation in hypothyroid $\operatorname{rats}^{[7]}$. Rodriguez et al. (2009) stated that salivary glands have a high metabolism, requiring energy for composition, synthesis, and secretion of saliva which is not available in a hypothyroid state ${ }^{[17]}$. This was furtherly discussed by other studies who declared that the thyroid hormone facilitates DNA transcription resulting in new protein synthesis in the tissues. Therefore significant changes occurred in tissues of salivary glands ${ }^{[8]}$.

Blood vessels with marked congestion and cellular infiltration were seen in the interstitial space that was observed in hyperthyroidism and less congestion and cellular infiltration were noticed in hypothyroidism. This was in accordance with Treesh and Khair (2014) who confirmed congested blood vessels in the ovary of both hyperthyroid and hypothyroid rats ${ }^{[32]}$. Selim (2013) observed congested blood vessels and cellular infiltration in parotid gland of rats with a high-fat $\operatorname{diet}^{[33]}$. Saraji et al. (2012) also suggested that moderate parenchymal inflammation and edema were found in hyperthyroid $\operatorname{rats}^{[34]}$.

These findings were furtherly described by Hozumi et al. (1995) to be a part of the inflammatory response ${ }^{[35]}$. Redman (2008) added that these changes may restrict diffusion of nutrients and oxygen to parotid cells ${ }^{[36]}$. Khalawi et al. (2013) further explained that signs of inflammation as cellular infiltrations and fibrosis have the ability of oxidative stress to stimulate the expression of genes involved in collagen biosynthesis, which was confirmed in the present study by wide separation of acini by interstitial tissue in H\&E stained sections of hypothyroid rats and presence of collagen in ultra-thin sections in hyperthyroid rats ${ }^{[37]}$.

Examination of parotid semithin sections showed some decrease in secretory granules in the hyperthyroid group and marked decrease in the hypothyroid group, with the appearance of some lightly stained acini in H\&E sections of hypothyroid rats. This was in accordance with Olver (2006) who declared that hypothyroid patients suffered from reduced salivary flow (xerostomia) This would be attributed to the salivary glands' atrophy observed ${ }^{[17,38]}$. Pinto and Glick (2002) added that autoimmune diseases affect mouth health like Sjogren's syndrome, are more common in people with thyroid disease and documented burning mouth and increase susceptibility to dental caries in hyperthyroidism ${ }^{[39,40]}$.

Also, ultra-structural examination in the current study showed some electron-lucent secretory granules in hyperthyroidism with a decrease in the number of electrondense secretory granules. While in the hypothyroid group most of the secretory granules were electron-lucent with few electron-dense granules. In accordance with this Selim (2013) observed electron-lucent secretory granules in the degenerated parotid gland. Some studies stated that reactive oxygen species and oxidative stress leads to lipid peroxidation, inhibition of the protein synthesis and fragility of the granules ${ }^{[33,41,42]}$. Maciejczyk et al. (2018) 
added that a decrease in the salivary flow occurred when rats were subjected to oxidative stress by high sucrose diet consumption ${ }^{[43]}$.

The ultrastructural examination of sections showed irregular acinar cells nuclei in hyperthyroidism and irregular heterochromatic nuclei in hypothyroidism. Ayoub (2016) demonstrated some degenerated salivary glands cells with darkly stained cytoplasm and pyknotic nuclei in hypothyroid rats ${ }^{[12]}$. Treesh and Khair (2014) observed atrophied ovarian follicles in hypothyroid rats ${ }^{[32]}$.

Ultrastructural examination in the present study showed dilated rough endoplasmic reticulum in hypothyroidism. Some authors have observed that the dilated rough endoplasmic reticulum is associated with the changes in cells that precedes apoptosis ${ }^{[44]}$.Younis et al. (2013) observed dilated rough endoplasmic reticulum, degenerated mitochondria with coarse vacuoles on parotid gland on giving botulinum toxin A which inhibits salivary gland production ${ }^{[45]}$.

Also, vacuoles of different sizes were seen in the present study in hypothyroid rats while few vacuoles were noticed in hyperthyroid rats. El-bakry et al. (2010 ${ }^{[46]}$ mentioned the same observation when compared between effect of induced hypothyroidism and hyperthyroidism on brain region. They explained that happened due to lipid peroxidation and oxidative stress that leads to damage of cell membrane, increase in water content and swelling.

Moreover, El Gharmawy (2015) explained that the main organelles affected by oxidative stress were mitochondria and endoplasmic reticulum as a result of depriving the cell of energy production ${ }^{[47]}$. Saggu et al. (2010) reported similar changes in the sequence of cell apoptosis ${ }^{[48]}$.

Some studies declared that thyroid dysfunction including autoimmune thyroiditis affects both the quality and quantity of saliva ${ }^{[49]}$. Other studies declared that autoimmune changes that occur in endocrine glands such as thyroid may also occur in exocrine glands such as the salivary glands because the process of both is secretion ${ }^{[50]}$.

There was a highly statistically significant increase in mast cells in hyperthyroidism and hypothyroidism. This was explained by Saglam et al. (2005) who stated that mast cell recruitment was the result of inflammation through the production of histamine, heparin, and tryptase ${ }^{[51]}$. Bischoff and Sellge (2002) declared the increase of mast cells in chronic inflammatory and fibrotic disorders ${ }^{[2]}$. Ashkavandi and Ashraf (2014) added that mast cell counts increased in benign and malignant salivary gland tumors ${ }^{[53]}$.

In the present work, immunohistochemical examination for bcl2 showed strong immune reaction for bcl2 in the cytoplasm of parotid cells of the control group, the moderate immune reaction for bcl2 in hyperthyroid group \& weak immune reaction in hypothyroid group. This was in accordance with Abd Elazeem et al. $(2016)^{[7]}$ who explained that BCL-2 family proteins are anti-apoptotic factors so they act as an apoptosis regulator and it has an crucial role in inhibiting proapoptotic proteins actions. The decrease in immune reaction of $\mathrm{BCl}-2$ in case of hyperthyroidism and hypothyroidism revealed affection of normal cell physiology due to reactive oxygen species and apoptosis $^{[54]}$.

\section{CONCLUSIONS}

Both hyperthyroidism and hypothyroidism produce amelioration in the histology of the parotid gland tissue but with hypothyroidism histological changes in the glandular tissue are worse. So the normal levels of thyroid hormones are essential for parotid gland normal function.

It is recommended in cases of thyroid dysfunctions to monitor oral and dental health to follow salivary glands dysfunction.

\section{FUNDING}

This research did not receive any specific grant from funding agencies in the public, commercial, or not-forprofit sectors.

\section{CONFLICTS OF INTEREST}

There are no conflicts of interest.

\section{REFERENCES}

1. Rabeh, N.M. and El-Ghandour, H.A.: Effect of Iron, Zinc, Vitamin E and Vitamin C Supplementation on Thyroid Hormones in Rats with Hypothyroidism. International Journal of Nutrition and Food Sciences. (2016) 5(3): 201-210.

2. Kandir, S. and Keskin, E.: Effects of hypothyroidism and hyperthyroidism on hematological parameters in rats. Ankara Üniv. Vet. Fak. Derg. (2016) 63(4): 371-376.

3. Ferreira, E.; Silva, A.E.; Serakides, R. et al.: Model of induction of thyroid dysfunctions in adult female mice. Arq. Bras. Med. Vet. Zootec. (2007) 59 (5): 1245-1249.

4. Hashem, H.A.; El-Metwaly, H.; Mobarak, Y.M. et al: Impact of Induced Thyroxine and Carbimazole Vacillation on Liver of Female Rats. Egypt. Acad. J. Biolog. Sci. (2016) 8(2): 15-29.

5. Soliman, G.Z.A.: Effects of Hyperthyroidism on Lipid Profile, adiponectin and liver function tests in male albino rat. Indian journal of applied research (2013) 3(9): 14-17.

6. Nazifi, S.; Mansourian, M.; Nikahval, B. et al: The relationship between serum level of thyroid hormones, trace elements and antioxidant enzymes in dromedary camel (Camelus dromedarius). Trop Anim Health Prod. (2009) 41(1):129-134.

7. Abd Elazeem, A.; Mohammed, M.Z.; and Hassan, E.Z.: Effect of Experimentally Induced Hypothyroidism on the Parotid Gland of Adult 
Male Albino Rats and the possible Role of Thyroid Hormone Supplementation. British Journal of Science (2016) 14 (1): 19-36.

8. deJesus, V.C.; Beanes, G.; Paraguassú, G.M. et al: Influence of laser photobiomodulation (GaAlAs) on salivary flow rate and histomorphometry of the submandibular glands of hypothyroid rats. Lasers Med Sci. (2015) 30 (4):1275-1280.

9. Işman, C.A.; Yeğen, B.C. and Alican, I.: Methimazole-induced hypothyroidism in rats ameliorates oxidative injury in experimental colitis. Journal of Endocrinology (2003) 177 (3): 471-476.

10. Kim, S.M.; Kim, S.C.; Chung, I.K.etal: Antioxidant and Protective Effects of Bupleurum falcatum on the 1 -Thyroxine-Induced Hyperthyroidism in Rats. Evidence-Based Complementary and Alternative Medicine (2012) 578497: 1-12.

11. Panda, S. and Kar, A.: Amelioration of L-thyroxineinduced hyperthyroidism by coumarin (1, 2-benzopyrone) in female Rats. Clinical and Experimental Pharmacology and Physiology (2007) 34(11): 1217-1219.

12. Ayuob, N.N.: Histological and immunohistochemical study on the possible ameliorating effects of thymoquinone on the salivary glands of rats with experimentally induced hypothyroidism. The Egyptian Journal of Histology (2016) 39 (2): 125-135.

13. Hayat, N.Q.; Tahir, M.; Munir, B. et al: effect of methimazole-induced hypothyroidism on histological characteristics of parotid gland of albino rat. J Ayub Med. Coll. Abbottabad (2010) 22(3):22-27.

14. Cortés, C.; Eugenin, E.; Aliaga, E. et al: HypothyroidismintheAdultRatCauses Incremental Changes in Brain-Derived Neurotrophic Factor, Neuronal and Astrocyte Apoptosis, Gliosis, and Deterioration of Postsynaptic Density. Thyroid (2012) 22(9):951-963.

15. SUR, D.: Methimazole-induced hypothyroidism in rats: effect of methimazole-induced cellular damage on heart, lung and ovary. International Journal of Applied and Natural Sciences (IJANS) (2014) 3 (4): 21-28

16. Deshpande, U.R.; Joseph, L.J.; Patwardhan, U.N. et al: Effect of antioxidants (vitamin C, E and turmeric extract) on methimazole induced hypothyroidism in rats. Indian Journal of Experimental Biology (2002) 40 (6): 735-738.

17. Rodriguez, T.T.; Trocoli, V.; Dantas, A. et al:: Participation of nitric oxide synthase and cyclooxygenase- 2 in the salivary secretion of hypothyroid endotoxemic rats. Rev Odonto Ciênc. (2009) 24(4):383-388.

18. Simões, A.; Nicolau, J.; de Souza, D.N. et al: Effect of defocused infrared diode laser on salivary flow rate and some salivary parameters of rats. Clin. Oral Investig. (2008) 12(1):25-30.

19. Leal, S.C.; Toledo, O.A. and Bezerra, A.C.: Morphological Alterations of the Parotid Gland of Rats Maintained on a Liquid Diet. Braz. Dent. J. (2003) 14(3): 172-176.

20. Zalewska, A.; Knas', M.; Kuzmiuk, A et al: Salivary innate defense system in type 1 diabetes mellitus in children with mixed and permanent dentition. Acta Odontol. Scand. (2013) 71 (6): 1493-1500.

21. Zalewska, A.; Knas', M.; GindzienskaSieskiewicz, E. et al: Salivary antioxidants in patients with systemic sclerosis. J. Oral Pathol. Med. (2014) 43(1): 61-68.

22. Ostuni, M.A.; Houssay, A.B. and Tumilasci, O.R.: Modulation by thyroid hormones of rat parotid amylase secretion stimulated by 5hydroxytryptamine. Eur. J. Oral Sci. (2003) 111(6): 492-496.

23. El-Wakf, A.M.; Hassan, H.A.; Elsaid, F.G. et al: Hypothyroidism in male rats of different ages exposed to nitrate polluted drinking water. Research Journal of Medicine and Medical Sciences (2009) 4(2): 160-164.

24. Oncu, M.; Kanter, M.; Gokcimen, A. et al: Effect of thyroidectomy on the histology of rat sublingual gland. APMIS (2004) 112(2):119-122.

25. Bancroft, J.D. and Gamble, M.: Theory and practice of Histological techniques, 6th ed. Churchill Livingstone, London, Elsevier. (2008): 377-694.

26. Woods, A. and Stirling, J.: Electron Microscopy: The preparative techniques. In Bancroft, J. and Gamble, M. (ed): Theory and Practice of Histological Techniques, 5th ed. Churchill Livingston, New York, Edinburgh, London. (2002): 682-700.

27. Ikeda, R.; Aiyama, S. and Redman, R.S.: Effects of Exogenous Thyroid Hormone on the Postnatal Morphogenesis of the Rat Parotid Gland. Anat Rec (Hoboken) (2008) 291(1):94-104.

28. Tachibana, M. and Hagino, Y.: Amylase release from parotid glands of hypothyroid rats. I. Altered responsiveness to adrenergic agents. Jpn J Pharmacol. (1982) 32(6):1093-1101.

29. Ajayi, A.F.; Akhigbe, R.E. and Ajayi, L.O.: Hypothalamic-pituitary-ovarian Axis in Thyroid 
Dysfunction. West Indian Med J. (2013) 62 (9): 835-838.

30. Dale, J.; Daykin, J.; Holder, R. et al: Weight gain following treatment of hyperthyroidism. Clinical endocrinology (2001) 55(2):233-239.

31. Bano, S.; Ghafoor, S. and Naseem, N.: Effect of thyroid hormone on the histology of rat submandibular salivary gland during postnatal development. J Pak. Dent. Assoc. (2018) 27(1):37-42.

32. Treesh, S.A. and Khair, N.S.: Effect of Thyroid Disorders on the Adult Female Albino Rats (Histological and Histochemical Study). Journal of Cytology \& Histology (2014) 5 (4):1-9.

33. Selim, S.A.: The effect of high-fat diet-induced obesity on the parotid gland of adult male albino rats: histological and immunohistochemical study. The Egyptian Journal of Histology (2013) 36 (4): 772-780.

34. Saraji, A.A, D.; Doroudian, M.; Soezi, M. et al: The effect of hyperthyroidism on the levels of liver enzymes in adult male Wistar rats. Journal of Paramedical Science (2012) 3(4):36-42.

35. Hozumi, T.; Yoshida, M.; Ishida, Y. et al: Longterm effects of dietary fiber supplementation on serum glucose and lipoprotein levels in diabetic rats fed a high cholesterol diet. Endocr. J. (1995) 42(2):187-192.

36. Redman, R.S.: On approaches to the functional restoration of salivary glands damaged by radiation therapy for head and neck cancer, with a review of related aspects of salivary gland morphology and development. Biotec. Histochem. (2008) 83(3-4):103-130

37. Khalawi, A.A.; Al-Robai, A.A.; Khoja, S.M. et al: Can Nigella Sativa Oil (NSO) Reverse Hypothyroid Status Induced by PTU in Rat? Biochemical and Histological Studies. Life Science (2013) 10(2): 802-811.

38. Olver, I. N.: Xerostomia: a common adverse effect of drugs and radiation. Aust. Prescr. (2006) 29(4):97-98

39. Pinto, A. and Glick, M.: Management of patients with the thyroid disease: Oral health considerations. J Am Dent Assoc. (2002) 133(7):849-858

40. Chandna, S. and Bathla, M.: Oral manifestations of thyroid disorders and its management. Indian J. Endocrinol. Metab. (2011) 15(Suppl2): S113-S116.

41. Verma, R.J. and Nair, A.: Effect of aflatoxins on testicular steroidogenesis and amelioration by vitamin E. Food Chem. Toxicol. (2002) 40(5): 669-672.
42. Stevens, T.; Conwell, D.L. and Zuccaro, G.: Pathogenesis of chronic pancreatitis: an evidence-based review of past theories and recent developments. Am. J. Gastroenterol. (2004) 99(11):2256-2270.

43. Maciejczyk, M.; Matczuk, J.; ŻendzianPiotrowska, M. et al: Eight-Week Consumption of High-Sucrose Diet Has a Pro-Oxidant Effect and Alters the Function of the Salivary Glands of Rats. Nutrients (2018) 10(10): 1530.

44. Takahashi, S.; Nakamura, S.; Domon, T. et al: Active participation of apoptosis and mitosis in sublingual gland regeneration of the rat following release from duct ligation. J. Mol. Histol. (2005) 36(3):199-205.

45. Younis, R.E.; Abou Elkhier, M.T.; Mourad, M.I. et al: Ultrastructural changes in the parotid gland of rats after intraglandular injection of botulinum toxin A. Annals of Oral \& Maxillofacial Surgery (2013) 1(4):38

46. El-bakry,A. M.; El-Gareib,A. W. and Ahmed, R. G.: Comparative study of the effects of experimentally induced hypothyroidism and hyperthyroidism in some brain regions in albino rats. Int. J. Devl Neuroscience (2010) 28(5): 371-389.

47. ElGhamrawy, T.A.: The effect of liquid diet on the parotid gland and the protective role of L-carnitine: immunohistochemical and ultrastructural study. Folia Morphol. (2015) 74 (1): 42-49.

48. Saggu, S.K.; Chotaliya, H.P.; Blumbergs, P.C et al: Wallerian-like axonal degeneration in the optic nerve after excitotoxic retinal insult: an ultrastructural study. BMC Neurosci. (2010) 11: 97.

49. Syed, Y.A.; Reddy, B.S.; Ramamurthy, T.K. et al: Estimation of Salivary Parameters among Autoimmune Thyroiditis Patients. Journal of Clinical and Diagnostic Research (2017)11(7): ZC01-ZC04.

50. Szanto, A.; Csipo, I.; Horvath, I. et al: Autoantibodies to alfa-fodrin in patients with Hashimoto thyroiditis and Sjögren's syndrome: possible markers for a common secretory disorder. Rheumatology International (2008) 28(11): 1169-1172.

51. Saglam, B.; Cikler, E.; Zeybek, A. et al: Protective effects of 2-mercaptoethane Sulfonate (MESNA) on Protamine Sulfate induced bladder damage. Marmara Medical J. (2005) 18(1):6-12.

52. Bischoff, S.C. and Sellge, G.: Mast cell hyperplasia and role of cytokines. International Archives of Allergy and Immunology (2002) 127(2):118-122. 
53. Jaafari-Ashkavandi, Z. and Ashraf, M.J.: Increased Mast Cell Counts in Benign and Malignant Salivary Gland Tumors. J Dent Res Dent Clin Dent Prospects (2014) 8(1):15-20.
54. Hardwick, J.M. and Soane, L.: Multiple functions of BCL-2 family proteins. Cold Spring Harb Perspect. Biol. (2013) 5(2): a008722. 


\title{
الملخص العربى
}

\section{دراسة مقارنة بين تأثير فرط ونقص نشاط الغدة الدرقية المستحدث علي الغدة النكفية في ذكور الجرذان البيضاء البالغة سئة}

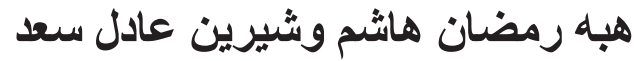 \\ قسم التشريح وعلم الأجنة، كلية الطب ، جامعة وين عين شمس، القاهرة، مصر سعر
}

مقدمة: يعتبر قصور الغدة الدرقية أحد أهم أمر اض الغدد الصماء.التغيير في مستوي هرمونات الغدة يؤدي الي تغييرات سريرية مختلفة. تعمل الغدد اللعابية كخط الدفاع الأول لتجويف الفم والأسنان. أي تغيير ات في سلامتها ونشاطها يمكن أن يؤثر على صحة المريض. سن.

الهدف من البحث: تهدف هذه الدر اسة إلى مقارنة التغييرات الهستولوجية الوظيفية المحتملة التي قد تحدث في تركيب الغدة النكفية في حالة فرط نشاط الغدة الدرقية وحالة نقص نشاط الغدة الدرقية. المواد وطرق البحث: استخدم في هذه الدر اسة عدد أربعة و عشرون من الجرذان الذكور البيضاء البالغة وقسمت الي ثلاث مجمو عات متساوية: المجمو عة الأولي: كمجمو عة ضابطة, المجموعة الثانية (مجموعة زيادة نشاط الغدة): تلقت الجرذان عقار الالتروكسين بجر عة . . 7 ميكرو غر ام / كغ / يوم عن طريق الفم لمدة ثلاثة أسابيع مثتالية. المجمو عة الثالثة (مجمو عة نقص نشاط الغدة الدرقية): تلقت الجرذان عقار النيومركازول بجرعة هب, ا ملغم / كغم / يوم عن طريق الفم لمدة ثلاثة أسابيع متتالية. في نهاية التجربة ، ثم وزن جميع الجرذان ، وجمع عينات الدم ، ثم ثم التضحية بهم جميعًا. تم وزن الغدد النكفية

$$
\text { و أخذ عينات للفحص النسيجي و المناعي و التركيب الدقيق. }
$$

النتائج: أظهر فحص الغدة النكفية في كل من المجموعة الثانية و الثالثة تغيرات نسيجية متفاوتة علي شكل انتفاخ بحويصلات الغدة، اتساع بقناة الغدة، تغير في كثافة حبيبات الإفراز ، احتقان بالأوعية الدموية و التسلل الخلوي. وير افق ذلك تغيير ات كبيرة في وزن الغدة النكفية ، وزن الجسم ، و عدد الخلايا البدينة. الخلاصة: يوصى في حالات اختلال وظائف الغدة الدرقية مر اقبة صحة الفم والأسنان لمتابعة الخلل الوظيفي للغدد اللعابية. 